\title{
Nutrient management through soil and foliar application on production maximization of rainy season groundnut
}

\author{
H. PATRO, M.A. ALIM AND A.K. BEHURA
}

Received : 12.05.2014; Revised : 17.09.2014; Accepted : 03.10.2014

\author{
MEMBERS OF RESEARCH FORUM: \\ Corresponding author : \\ H. PATRO, Department of Agronomy, \\ AICRPG on Groundnut Orissa \\ University of Agriculture and \\ Technology, BHUBANESWAR (ORISSA) \\ INDIA \\ Email: hrusikesh.patro1@gmail.com
}

Co-authors :

M.A. ALIM, Department of Agronomy, AICRIP, Orissa University of Agriculture and Technology, Chiplima, Sambalpur, COIMBATORE (T.N.) INDIA

A.K. BEHURA, Department of Agronomy, College of Agriculutre, Orissa University of Agriculture and Technology, BHUBANESWAR (ORISSA) INDIA

\section{Summary}

Integrated use of .organic and inorganic fertilizers can improve crop productivity and sustain soil health and fertility. The present experiment was conducted during rainy season of 2011, 2012 and 2013 at groundnut Research Farm, Orissa University of Agriculture and Technology, Odisha to study the effect of nutrient management practices on maximizing the production of groundnut crop. The results revealed that different nutrient management practices exerted significant influence on pod yield and yield attributes of groundnut under rain fed conditions. Application of FYM @ $7.5 \mathrm{t} / \mathrm{ha}$ plus recommended dose of NPK/ha $(20 \mathrm{~kg} \mathrm{~N}, 40 \mathrm{~kg}$ $\mathrm{P}_{2} \mathrm{O}_{5}$ and $40 \mathrm{~kg} \mathrm{~K} \mathrm{O} / \mathrm{ha}$ ) along with soil application of critical micronutrients $(10 \mathrm{~kg}$ borax/ha) produced higher pod yield (1457 kg/ha) and higher net monetary returns (Rs.7096/ha) as compared to application of recommended dose of NPK/ha with or without FYM @ 7.5 t/ha (1332kg/ha, Rs. $5305 / \mathrm{ha}$ and $1105 \mathrm{~kg} / \mathrm{ha}$, Rs. $2710 / \mathrm{ha}$, respectively). The same treatment recorded significantly highest number of root nodules per plant at $40 \mathrm{DAS}(15.6)$ and 80 DAS (18.9) and maximum number of pods/plant (18.6) 100 kernel weight (33.0) and shelling per cent (64.2) as compared to other fertility levels. Foliar application of urea also significantly influenced pod yield of groundnut. However, foliar application of urea @ 2 per cent at 30 and 60 DAS exhibited maximizing pod yield of $1350 \mathrm{~kg} / \mathrm{ha}$ which is 11.6 per cent higher than no foliar application $(1210 \mathrm{~kg} / \mathrm{ha})$. It was concluded that to get maximum productivity and profitability from groundnut during rainy season in acidic soils of Odisha, the crop should be managed with $7.5 \mathrm{t} \mathrm{FYM/ha}+100$ per cent recommended dose of fertilizer as basal + foliar spray of 2 per cent urea at 30 and 60 DAS.

Key words : Nutrient, Production maximisation, Management, Rainy season groundnut, Nutrient, Farm yard manure

How to cite this article : Patro, H., Alim, M.A. and Behura, A.K. (2014). Nutrient management through soil and foliar application on production maximization of rainy season groundnut. Asian J. Soil Sci., 9(2): 165-168. 